\title{
Dr. Roberto Miguel Klein Herbarium (FURB), Blumenau, Southern Brazil
}

\author{
André Luís de Gasper ${ }^{1,2}$, Alexander Christian Vibrans², Luís Adriano Funez², \\ Morilo José Rigon-Jr' ${ }^{2}$, Felipe Bittencourt ${ }^{2}$, Carina Vieira ${ }^{2}$ \\ I Herbarium Curator 2 Universidade Regional de Blumenau (University of Blumenau). Antônio da Veiga, \\ 140 - Victor Konder. CEP: 89012-900 - Blumenau - Santa Catarina-Brasil
}

Corresponding author: André Luis de Gasper (algasper@gmail.com)

Academic editor: L. Penev | Received 18 December 2013 | Accepted 17 September 2014 | Published 13 October 2014

Citation: Gasper AL, Vibrans AC, Funez LA, Rigon-Jr MJ, Bittencourt F, Vieira C (2014) Dr. Roberto Miguel Klein Herbarium (FURB), Blumenau, Southern Brazil. PhytoKeys 42: 21-37. doi: 10.3897/phytokeys.42.6865

\begin{abstract}
The premise of this study is to present the collection of the FURB herbarium, its collection area and type specimens, as well as its projects and contributions to the flora of the Subtropical Atlantic Forest. The FURB herbarium currently has nearly 41,000 records of vascular plants and has the largest collection of lycophytes and ferns in Southern Brazil, with more than 8,000 records. More than 4,500 scanned images of 4,436 species are available online, and it is expected that the whole collection will be scanned in less than one year. There are 198 families of angiosperms, 33 of ferns, three of lycophytes and six of gymnosperms. All collections of the Floristic and Forest Inventory of Santa Catarina project are recorded in FURB, which represents almost 35,000 herbarium specimens. The families with the largest number of species are: Cyperaceae (109 species), Rubiaceae (129), Solanaceae (131), Poaceae (155), Melastomataceae (157), Myrtaceae (257), Orchidaceae (288), Fabaceae (323), and Asteraceae (426), between angiosperms. Among the ferns and lycophytes are: Hymenophyllaceae (30), Thelypteridaceae (31), Aspleniaceae (32), Dryopteridaceae (43), Pteridaceae (54) and Polypodiaceae (60). There are five type specimens among them: one holotype, one isotype and three paratypes. To date, the FURB herbarium has donated 19,521 herbarium duplicates for identification or expansion of other herbaria.
\end{abstract}

\section{Keywords}

Catalogue, Scientific collection, Regional University of Blumenau, Ferns, Vascular plants, Spermatophyta, Pteridophyta, Compositae, Leguminosae, Southern Brazil, Rain Forest, Evergreen Rainforest, National Parks, Biodiversity

Copyright André Luis de Gasper et al. This is an open access article distributed under the terms of the Creative Commons Attribution License (CC BY 4.0), which permits unrestricted use, distribution, and reproduction in any medium, provided the original author and source are credited. 


\section{Introduction}

The Dr. Roberto Miguel Klein Herbarium (FURB) was founded in 1990 by Lucia Sevegnani, PhD. Roberto Miguel Klein (1923-1992) was an important botanist and ecologist. In 1949, together with Father Raulino Reitz, he founded the Sellowia Journal, which published contributions of researchers linked to Herbário Barbosa Rodrigues (HBR). In addition to HBR, the Sellowia papers are considered Klein's major works, among those that treated the relation between malaria outbreaks and the local flora (Klein 1967) and addressed the vegetation structure of Southern Brazil, published in a series of papers co-authored by Henrique Pimenta Veloso (Veloso and Klein 1957, 1959, 1961, 1963, 1968a, 1968b).

Klein and Reitz also created the Flora Ilustrada Catarinense (Reitz 1965; CitadiniZanette 2013), published in 149 fascicles between 1965 and 1989. In addition to conducting a floristic assessment of Santa Catarina State, Klein studied autoecology and gathered information about tree communities, making himself one of the outstanding dendrologists of Southern Brazil (Amado 2013). His importance has been proven by tributes such as the genus Kleinodendron L.B.Sm. \& Downs, besides 75 specific epithets, from 37 families (IPNI 2012). After his death, Klein's scientific contributions were not forgotten. The Flora Ilustrada Catarinense came to be published from 1996 on, with 17 volumes published to date (Bortoluzzi et al. 2011).

The FURB herbarium has been registered in Index Herbariorum since 2005, under the acronym FURB (http://sweetgum.nybg.org/ih/herbarium.php?irn=148203). The aim of the herbarium is to study the plant diversity of the local vegetation, especially that of the Serra do Itajaí National Park, Itajaí Valley, and Santa Catarina State. Initially the collection was established by professors for didactic purposes, but with the advent of new projects, such as the Floristic and Forest Inventory of Santa Catarina (IFFSC project - Vibrans et al. 2010), the collection has undergone a massive increase in the amount of material. At the beginning of the IFFSC project, the FURB herbarium had only approximately 5,000 herbarium specimens (now there are more than 41,000$)$. At present, $86 \%$ of the FURB collection is georeferenced, with only a few early specimens not having coordinates.

The software that is used has been developed especially for the herbarium and the data has become available online, in INCT databases (http://inct.splink.org.br/), SpeciesLink (http://splink.cria.org.br/), and Reflora (http://reflora.jbrj.gov.br). The software (Herbaria 3.1), an Access-based software, has been developed by EPAGRI (http://www.epagri.sc.gov.br) in partnership with the herbarium staff (for more information see Miszinski et al. 2012).

The angiosperm collections are organized according to the APG system (Reveal and Chase 2011), the ferns according to Rothfels et al. (2012) and Smith et al. (2006), the lycophytes according to Øllgaard (2012), and the gymnosperms according to Christenhusz et al. (2011). 


\section{Data resources}

The data underpinning the analyses reported in this paper are deposited in the GBIF, the Global Biodiversity Information Facility, http://ipt.pensoft.net/ipt/resource. do?r=furb_herbarium_database_11-09-2014

\section{Available data}

The herbarium has 41,325 specimens (Figure 1 and Figure 2), in addition to the largest collection of ferns and lycophytes (8,360 specimens) in Santa Catarina State. The full database is available via the INCT Virtual Herbarium (http://inct.splink.org.br/ FURB). There are 4,556 images of 4,436 species.

\section{Recent projects}

\section{Flora Catarinense Revisited}

This project aims to find the nomenclatural types collected in Santa Catarina in herbaria and publications; recollect specimens in the field in the type localities, mainly the older ones; scan nomenclatural types; perform collections; and get information about rare and endemic species that are only known by the type or by very few documented specimens in collections.

\section{IFFSC - Floristic and Forest Inventory of Santa Catarina State}

This project aims to develop the floristic inventory of forest formations in Santa Catarina and generate information to support the formulation of forest policy in the state, in particular the economic-ecological zoning for rural land use planning and environmental licensing, as well as the defining of priority areas for conservation, restoration of degraded ecosystems, and the updating of red lists. To complete these objectives, the remaining forests are periodically inventoried and their horizontal and vertical structures analyzed. The genetic diversity and structure of populations of 13 endangered species are assessed, as well as the social and economic importance of the state's native forest resources. Finally, a georeferenced information system has been designed and implemented and is to be updated in order to assist the preparation of the endangered species list. The project publications can be downloaded from the IFFSC website (http://www.iff.sc.gov.br/ - Vibrans et al. 2013a, 2013b, 2013c, 2012a, 2012b). 


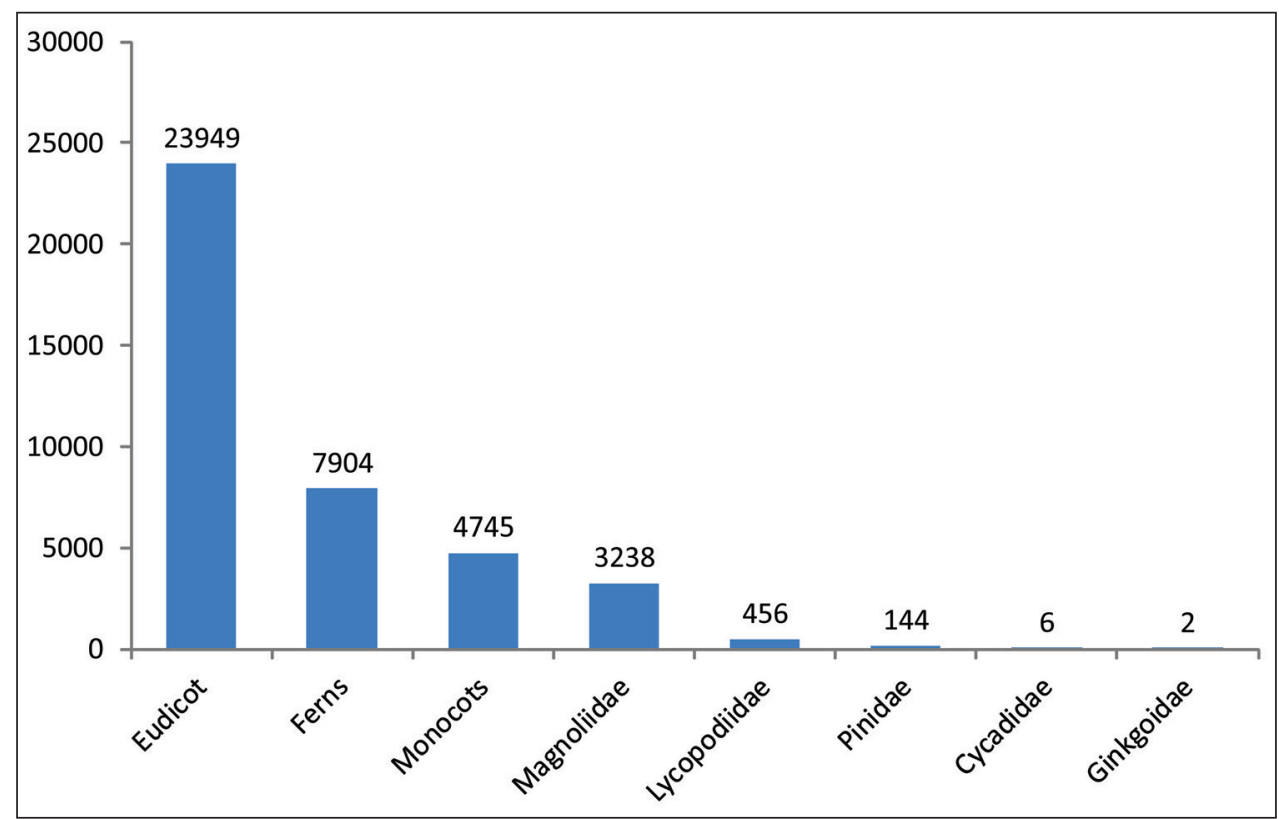

Figure I. Number of specimens distributed among the division of vascular plants.

\section{DNA bank}

The establishment of a DNA database linked to the FURB herbarium aims to provide subsidies for studies in molecular biology including species of flora of Santa Catarina. In Brazil these initiatives have been shown to be necessary, since, despite the enormous biodiversity of the flora of the country, molecular studies are scarce (Santos et al. 2002). The bank starts in 2014 with the goal of maintaining samples of the main species of Santa Catarina's vascular plants and fungi. Field surveys will be performed and samples collected from young leaves will be stored in silica gel. This inexpensive andeffective method, neither injurious to the DNA nor detrimental to the dehydration of leaves (Chase and Hills 1991), grants researchers the ability to preserve the DNA material for at least 10 years (Hodkinson et al. 2007), reducing the costs of research and allowing material to be donated and loaned. Gaudeul and Rouhan (2013) recommend a universalization of the method and this should be done in any field, since it is practical, avoids surveys in specific fields for this purpose, and increases the scientific value of the specimens and collection. In fact, other field surveys will be done, in addition to those related to the project, to ensure the existence of samples in DNA database. In the first year, the collections will prioritize the Itajaí Valley region of the state, which is home to 54 municipalities, and it estimated that at least $20 \%$ of the tree species will be collected and made available for study. The sample for the DNA bank will continue with the second cycle of IFFSC, whose collections will be performed throughout the state, and it is estimated that material will be collected for DNA extraction for about $75 \%$ of the tree species. The database of the species can be found at www.furb.br/herbarium. 


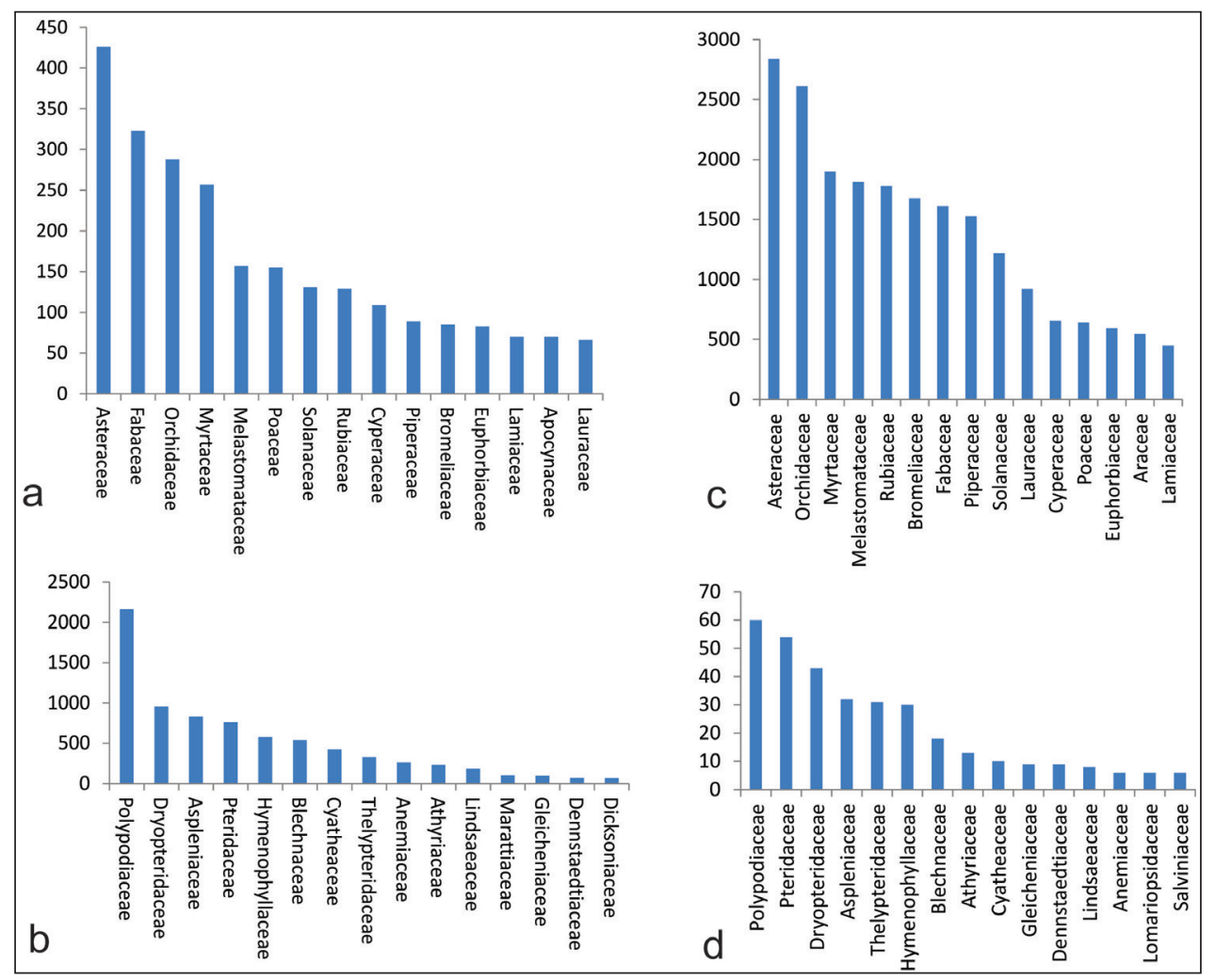

Figure 2. Number of specimens of the main families of angiosperms (a), ferns and lycophytes (b) in FURB collection. Number of specimens of angiosperms (c), ferns and lycophytes (d).

\section{Temporal coverage}

The earliest specimen is dated March 1, 1937, a Prosopis nigra Hieron. (Fabaceae), but the first specimen for the FURB herbarium was collected on September 7, 1991, of a Plinia rivularis (Cambess.) Rotman. (Myrtaceae). The distribution of collected specimens by year can be seen in Figure 3. A great increase occurred between 2007 and 2012, during the first cycle of the IFFSC project. The second cycle of the project will start in 2014 and will surely result in an increase of the the number of specimens.

\section{Plant sampling}

Most of the plant samples are from Southern Brazil, Santa Catarina State (Figure 4) being the most widely represented area, and the aim is to cover the widest possible range of plant diversity of this territory. The majority of the samples comes from the IFFSC project and from the field work of undergraduate students. Other parts of the Brazilian South are represented mainly by exchanged samples. 


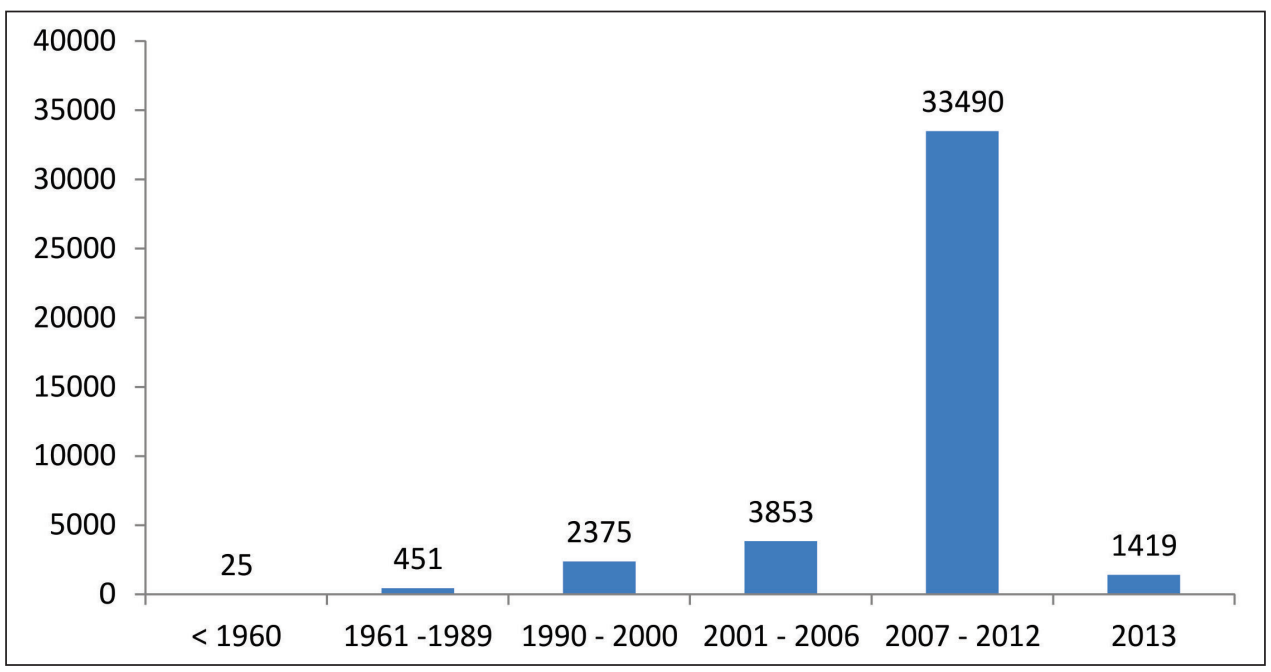

Figure 3. Temporal coverage of Herbarium FURB.

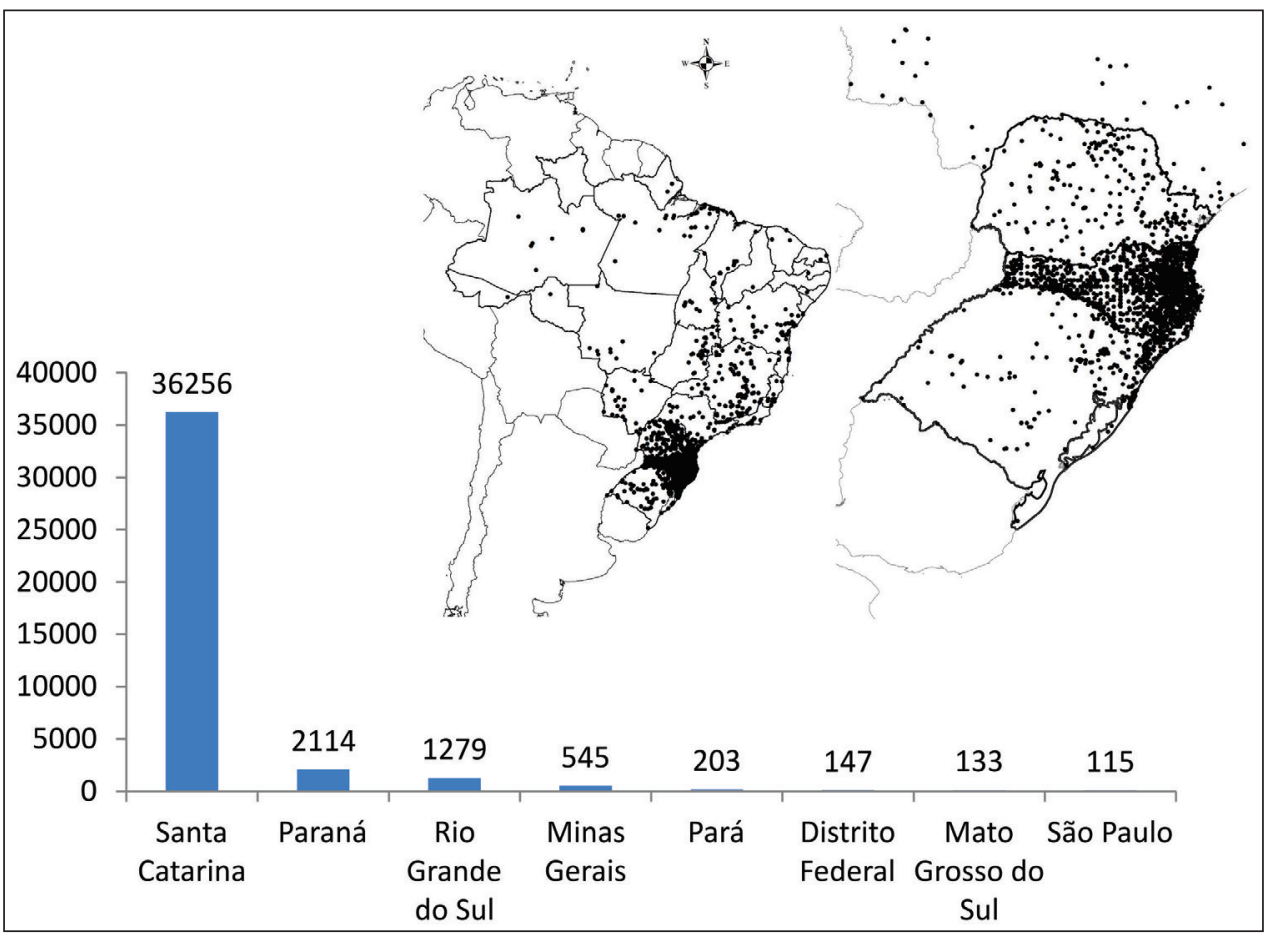

Figure 4. Spatial coverage of FURB collection. Only the hundred best states collected. 


\section{Plant processing procedures}

After being dried in ovens at 65 to 70 degrees Celsius, the specimens are incorporated into the database. All data such as scientific name, location, city, coordinates, altitude, and general descriptions of the plant are recorded. The registration number is generated automatically by the software. Afterwards, the plants are glued with hot glue onto A2 sheets, packed in plastic bags in order to avoid being contaminated by insects or fungi and to prevent loss of material during handling, and subsequently frozen for five days at -20 degrees Celsius. Next, the plants are stored in specific cans that are sealed and stored separately in groups: lycophytes and ferns, gymnosperms and angiosperms. Among the groups, the cans are alphabetized according to family and gender.

All databases are reviewed by a DataClean tool, from CRIA (http://splink.cria. org.br/dc/index?criaLANG=pt\&colecao=FURB), which checks the coordinates, toponymy, scientific names, and their authors. The "doubtful" records are reviewed by the curator. The names are checked using the List of Species of Brazilian Flora (2014), and the identifications are made by specialists visiting the herbarium or by comparison with photos or duplicates sent to other institutions.

The FURB herbarium uses a specific software, Herbaria 3.1 (Miszinski et al. 2012), that includes several control possibilities of the collection. These control possibilities include information about the synonymous names used, preventing the same species from being registered under several names. Thus, we use specific fields for family, genus, and specific epithet. When we enter a genus name, its family and division is automatically filled based on an ancillary table. A list of epithets linked to the genus is then released, allowing the choice of the same (new epithets can be linked at any time), which is chosen to fill the author's name and still shows the presence of varieties or subspecies.

\section{Rare, endemic species and ecosystems sampled}

FURB maintains 68\% of all species listed by the List of Species of Brazilian Flora (2014) for Santa Catarina and 33.9\% of all species in the Brazilian Atlantic Forest (Stehmann et al. 2009). The Atlantic Forest in Santa Catarina has three forest types: Evergreen Rainforest, Mixed Forest, and Seasonal Forest (for more information see Klein 1978 and Oliveira-Filho et al. 2013). 75\% of FURB samples were collected in Evergreen Rainforest, 16\% in Mixed Forest, and 5\% in Seasonal Forest. The other formations (grasslands, mangroves, and coastal vegetation) constitutes $4 \%$ of the collections. Species of natural grasslands are represented still less, but will increase due to sample campaigns to be held within the IFFSC project during 2014 and 2015. Furthermore, 27 species of the Brazilian Official List of Endangered Species (Brazil 2008) are represented in the collection, available for conservation and other studies, 19 of these being native of Santa Catarina. Of the 235 endemic species of Santa Catarina (Brazilian List of Species of Flora 2014), 52 are found in the herbarium. 
Table I. Number of specimens from main Conservation Units represented in the herbarium.

\begin{tabular}{l|c}
\hline Protected area & Species \\
\hline Morro do Baú Municipal Park & 101 \\
\hline Canela Preta Biological Reserve & 123 \\
\hline Prima Luna Private Reserve of Natural Patrimony & 159 \\
\hline Lagoinha do Leste Municipal Park & 165 \\
\hline Caraguatá Private Reserve of Natural Patrimony & 194 \\
\hline São Joaquim National Park & 211 \\
\hline Bugerkopf Private Reserve of Natural Patrimony & 248 \\
\hline Acaraí State Park & 260 \\
\hline Lagoa do Peri Municipal Park & 283 \\
\hline Dona Francisca Environmental Protection Area & 292 \\
\hline Serra do Tabuleiro State Park & 340 \\
\hline Rio Vermelho Humboldt Environmental Protection Area & 522 \\
\hline São Francisco de Assis Municipal Park & 592 \\
\hline Serra do Itajaí National Park & 2428 \\
\hline
\end{tabular}

The database SpeciesLink (http://splink.cria.org.br/) shows that the FURB herbarium possesses 0.0725 records per sq $\mathrm{km}$ of the Southern region. Although seemingly small, it is a high number compared to other featured herbaria in Santa Catarina; FLOR, JOI and CRI have $0.0677,0.0150$, and 0.0119 records per sq km, respectively. Among these herbaria, FURB also has the largest number of herbarium specimens with photographs available online (4,354 in total), and the goal is to start photographing all specimens before the end of 2014. It also deserves to be mentioned that the collection has 1,417 unique names not found in other herbaria. This is quite a high number despite the fact that, due to the impracticability of this analysis, possible synonyms were not excluded.

Although the flora of Santa Catarina is well documented in the FURB herbarium, recent studies are still reporting new records for the state (Gasper and Sevegnani 2010, Gasper et al. 2012b, Funez and Gasper, unpublished data), suggesting that there are even more species to find.

The Conservation Units are represented at FURB by 2,428 specimens collected in Serra do Itajaí National Park, the largest remaining area of Evergreen Rainforest (Atlantic Rain Forest), 4,771 specimens being collected in other Conservation Units (Table 1).

\section{Taxonomic coverage}

The main herbarium collection is composed of vascular plants (Figure 1), representing 4,267 species. Among the vascular plants is the collection of ferns (368 species and 7,904 specimens) and lycophytes (33 species with 456 specimens), which corresponds to $20 \%$ of the total specimens and $9,4 \%$ of the species. Bryophytes lato sensu corre- 
spond to $0,2 \%$ of the collection. There are 198 families of angiosperms (Figure 2), 33 of ferns, 3 of lycophytes and 6 of gymnosperms. There are 203 plants without identification. The main collections are from Santa Catarina State (Figure 4).

With the implementation of an exchange program and the aim of supporting other collections, the FURB herbarium has donated 19,521 herbarium specimens. The families with more than 500 duplicates donated are: Solanaceae (532 donations), Bromeliaceae (542), Aspleniaceae (612), Piperaceae (769), Orchidaceae (848), Myrtaceae (854), Melastomataceae (1,026), Rubiaceae $(1,054)$, Polypodiaceae $(1,156)$, Fabaceae $(1,257)$, Asteraceae (1,478), and Lauraceae (1,621). Likewise, 3,794 herbarium specimens have already been loaned to perform theses, dissertations, and other taxonomic studies.

It is worth mentioning that there are five types in the collection: Holotypus of Vriesea rubens J.G.Silva \& A.F.Costa (Bromeliaceae), isotypus of Croton pygmaeus L.R.Lima (Euphorbiaceae), paratypus of Calystegia brummittii P.P.A.Ferreira \& Sim.Bianch (Convolvulaceae), paratypus of Pleurostachys arcuate W.W. Thomas, M. Alves \& R. Trevis (Cyperaceae), and paratypus of Sarcoglottis catharinensis Mancinelli \& E.C.Smidt (Orchidaceae).

\section{Taxonomic ranks}

\section{Kingdom: Chlorobionta}

Subclass: Lycopodiidae (lycophytes), Equisetidae, Marattiidae, Ophioglossidae, Polypodiidae, Psilotidae (ferns), Ginkgoidae, Cycadidae, Pinidae, Gnetidae (gymnosperms), and Magnoliidae (angiosperms)

Lycophyte families: Isoetaceae (1 specimen/1 species); Lycopodiaceae (326/21) and Selaginellaceae (129/11).

Fern families: Anemiaceae (261 specimens/6 families); Aspleniaceae (833/32); Athyriaceae (234/13); Blechnaceae (542/18); Culcitaceae (1/1); Cyatheaceae (425/10); Cystopteridaceae (2/1); Davalliaceae (2/1); Dennstaedtiaceae (70/9); Dicksoniaceae (69/2); Dryopteridaceae (954/43); Equisetaceae (13/3); Gleicheniaceae (99/9); Hemidictyaceae (1/1); Hymenophyllaceae (578/30); Lindsaeaceae (185/8); Lomariopsidaceae (40/6); Lygodiaceae (32/1); Marattiaceae (104/5); Marsileaceae (3/3); Ophioglossaceae (25/4); Osmundaceae (12/2); Parkeriaceae (3/1); Plagiogyriaceae (2/1); Polypodiaceae (2163/60); Psilotaceae (5/1); Pteridaceae (760/54); Saccolomataceae (44/2); Salviniaceae (16/6); Schizaeaceae (25/2); Tectariaceae (68/4); and Thelypteridaceae $(330 / 31)$.

Gymnosperm families: Araucariaceae (17 specimens/3 species); Cupressaceae (59/10); Cycadaceae (6/3); Ginkgoaceae (2/1); Pinaceae (26/8); and Podocarpaceae (40/4).

Magnoliidae families: Acanthaceae (384 specimens/35 species); Achatocarpaceae (2/2); Actinidiaceae (1/1); Adoxaceae (15/3); Aizoaceae (3/2); Alismataceae (14/4); Alstroemeriaceae (23/4); Amaranthaceae (185), 23); Amaryllidaceae (51/13); Anacardiaceae (135/13); Annonaceae (271/23); Apiaceae (84/22); Apocynaceae (339/70); Aquifoliaceae (196/8); Araceae (547/35); Araliaceae (123/21); Arecaceae (154/14); 
Aristolochiaceae (13/6); Asparagaceae (15/6); Asteraceae (2839/426); Balanophoraceae (10/2); Balsaminaceae (7/1); Basellaceae (10/1); Begoniaceae (325/24); Berberidaceae (16/3); Bignoniaceae (271/53); Bixaceae (8/2); Boraginaceae (172/23); Brassicaceae (23/8); Bromeliaceae (1676/85); Burmanniaceae (11/1); Burseraceae (12/1); Cabombaceae (1/1); Cactaceae (356/28); Calceolariaceae (4/3); Calyceraceae (12/2); Campanulaceae (81/19); Canellaceae (17/2); Cannabaceae (65/4); Cannaceae (25/2); Capparaceae (18/3); Caprifoliaceae (32/7); Cardiopteridaceae (13/3); Caricaceae (11/3); Caryocaraceae (4/1); Caryophyllaceae (31/12); Casuarinaceae (8/1); Celastraceae (116/18); Ceratophyllaceae (1/1); Chloranthaceae (37/1); Chrysobalanaceae (44/13); Cleomaceae (5/2); Clethraceae (65/2); Clusiaceae (140/9); Combretaceae (46/14); Commelinaceae (176/19); Connaraceae (11/3); Convolvulaceae (133/33); Costaceae (15/4); Crassulaceae (3/1); Cucurbitaceae (124/26); Cunoniaceae (52/5); Cyclanthaceae (26/1); Cyperaceae (656/109); Dilleniaceae (60/7); Dioscoreaceae (36/10); Droseraceae (2/1); Ebenaceae (11/4); Elaeagnaceae (1/1); Elaeocarpaceae (43/5); Ericaceae (69/11); Eriocaulaceae (48/15); Erythroxylaceae (74/14); Escalloniaceae (27/5); Euphorbiaceae (594/83); Fabaceae (1611/323); Fagaceae (8/6); Gentianaceae (29/7); Geraniaceae (3/2); Gesneriaceae (364/25); Goodeniaceae (4/1); Griseliniaceae (18/1); Gunneraceae (8/1); Heliconiaceae (64/3); Hernandiaceae (1/1); Humiriaceae (8/2); Hydrangeaceae (1/1); Hydrocharitaceae (3/1); Hydroleaceae (5/1); Hypericaceae (35/5); Hypoxidaceae (7/1); Icacinaceae (3/1); Iridaceae (97/17); Juglandaceae (2/1); Juncaceae (59/9); Juncaginaceae (1/1); Krameriaceae (3/1); Lacistemataceae (5/3); Lamiaceae (448/70); Lauraceae (921/66); Lecythidaceae (4/2); Lentibulariaceae (15/5); Liliaceae (13/2); Linaceae (1/1); Linderniaceae (3/3); Loasaceae (4/2); Loganiaceae (69/8); Loranthaceae (56/5); Lythraceae (120/21); Magnoliaceae (26/3); Malpighiaceae (255/43); Malvaceae (388/66); Marantaceae (97/10); Marcgraviaceae (33/3); Melastomataceae (1811/157); Meliaceae (368/18); Menispermaceae (41/6); Menyanthaceae (5/1); Molluginaceae (3/1); Monimiaceae (297/12); Moraceae (259/24); Musaceae (5/3); Myristicaceae (16/4); Myrtaceae (1899/257); Nyctaginaceae (132/11); Nymphaeaceae (3/1); Ochnaceae (152/8); Olacaceae (25/2); Oleaceae (15/4); Onagraceae (166/18); Opiliaceae (2/1); Orchidaceae (2611/288); Orobanchaceae (22/6); Oxalidaceae (53/10); Papaveraceae (3/2); Passifloraceae (116/23); Paulowniaceae (7/1); Pentaphylacaceae (9/2); Peraceae (54/2); Phrymaceae (2/1); Phyllanthaceae (72/11); Phytolaccaceae (92/12); Picramniaceae (21/4); Piperaceae (1528/89); Pittosporaceae (1/1); Plantaginaceae (90/18); Platanaceae (2/1); Plumbaginaceae (3/2); Poaceae (641/155); Podostemaceae (3/1); Polygalaceae (93/11); Polygonaceae (110/21); Pontederiaceae (24/9); Portulacaceae (7/6); Primulaceae (427/21); Proteaceae (36/7); Quillajaceae (9/1); Ranunculaceae (25/6); Rapateaceae (3/2); Rhamnaceae (58/11); Rhizophoraceae (7/1); Rosaceae (178/17); Rubiaceae (1779/129); Rutaceae (256/23); Sabiaceae (32/1); Salicaceae (195/21); Santalaceae (59/10); Sapindaceae (435/40); Sapotaceae (100/15); Saxifragaceae (1/1); Schlegeliaceae (7/1); Schoepfiaceae (4/2); Scrophulariaceae (32/3); Simaroubaceae (14/4); Siparunaceae (5/1); Smilacaceae (68/4); Solanaceae (1218/131); Styracaceae (53/4); Symplocaceae (84/15); Talinaceae (15/1); Tamaricaceae (1/1); Theaceae (18/2); Thymelaeaceae (37/3); Trigoniaceae 
(19/1); Tropaeolaceae (2/1); Typhaceae (8/2); Urticaceae (208/25); Velloziaceae (6/5); Verbenaceae (286/38); Violaceae (47/8); Viscaceae (3/0); Vitaceae (53/8); Vivianiaceae (12/1); Vochysiaceae (28/15); Winteraceae (103/2); Xanthorrhoeaceae (2/1); Xyridaceae (27/11); and Zingiberaceae (27/8).

\section{Research activities}

Herbarium collections have a fundamental importance in biodiversity conservation, exhibiting aspects such as reducing the distribution of a particular species or accumulating information in regard to rare or endangered species (e.g. Schatz 2012; Iganci and Morim 2012), and they often serve as a starting point for conservation (Bridson and Forman et al. 1992; for more information see Pyke and Ehrlich 2010). Currently, many species are described using the herbarium specimens, and this fact according to Bebber et al. (2010), is one of the great frontiersof new species.

To date, the collection has enabled comprehensive floristic studies of the three forest types of Santa Catarina (Gasper et al. 2012a, 2013a, 2013b; Sevegnani et al. 2013a). Phytosociological analyses were conducted by Schorn et al. (2012), Lingner et al. (2013a), and Meyer et al. (2013a). Understory species and regeneration strata were researched by Meyer et al. (2012, 2013b, 2013c). Spatial distribution of vascular plant and fern diversity were analyzed by Gasper and Sevegnani (2010), Gasper et al. (2012b), and Uhlmann et al. (2012). The influence of environmental (geoclimatic) variables on species richness, composition, and distribution in forest remnants was investigated within Evergreen Rainforest by Lingner et al. (2013b), fern species being considered by Gasper et al. (2013c). Spatial patterns of Dicksonia sellowiana Hook. (Dicksoniaceae), a threatened species, have been described by Gasper et al. (2011) in a study that was also based on the FURB collection. Finally, the collection has enabled studies on secondary succession and the assessment of the conservation status of the sampled forests (Vibrans et al. 2012c; Sevegnani et al. 2013b, 2013c).

In the future, the phylogenetic information will be provided by the DNA stored in the bank and will be extremely important for taxonomic studies. For this reason it is crucial that incentives for research and the maintenance of herbarium activities continue.

\section{Current situation and future perspectives}

Of the 170 active herbaria listed in the Catalogue of the Brazilian Herbaria (http:// www.botanica.org.br/rede_herbarios.php), most have fewer than 50,000 records ( $80 \%$ according to Peixoto et al. 2006). It is estimated that the FURB herbarium will reach this value in two years, and in the meantime must have its registration approved as "Fiel Depositário" (Azevedo 2005; CGEN 2014).

In addition to the novelties promoted by the e-taxonomy, the availability of data online, including the recently added images, allows for the rapid updating of herbari- 
ums (Smith and Figueiredo 2009;. Smith et al. 2011), as well as the discovery of gaps in collections (Canhos et al. 2013).

Finally, one of the novelties of the FURB herbarium is the expansion of its fungi collection. This may result from the second cycle IFFSC, with the collection of macrofungi, which requires special care (Wu et al. 2004). The collection of macrofungi in the Herbarium FURB is small at presentand has only 159 specimens, stemmed mainly from sporadic collections of a small number of students.

\section{Acknowledgements}

The authors offers thanks to Joelma Miszinski (EPAGRI/CIRAM) for developing the Herbaria 3.1 software, the students that contributed to the increase of the herbarium, and the University of Blumenau for all of its support, and Kyle York for English review. Two reviewers provided comments and suggestions to the paper.

\section{References}

Amado T (2013) Histórico sobre a primeira edição de O Reino Vegetal de Rio do Sul. Sellowia - Anais Botânicos do Herbário Barbosa Rodrigues, 5-20.

Azevedo CMA (2005) Regulation to access to genetic resources and associated traditional knowledge in Brazil. Biota Neotropica 5(1): 19-27. doi: 10.1590/S1676-06032005000100002

Bebber DP, Carine MA, Wood JRI, Wortley AH, Harris DJ, Prance GT, Davidse G, Paige J, Pennington TD, Robson NKB, Scotland RW (2010) Herbaria are a major frontier for species discovery. Proceedings of the National Academy of Sciences 107.51: 22169-22171. doi: $10.1073 /$ pnas. 1011841108

Bortoluzzi RL da C, Reis A; Mantovani A, Bernardes ZHD (2011) Herbários Catarinenses. Ciência \& Ambiente 42: 171-181.

Brasil (2008) Ministério do Meio Ambiente (MMA). Instruçáo Normativa nº 6, de 23 de setembro de 2008. Lista oficial das espécies da flora brasileira ameaçadas de extinção. Diário Oficial [da República Federativa do Brasil], Brasília, DF, v. 145, n. 185, 24 set. 2008. Seção 1, 75-83.

Bridson DM, Forman L (1992) The Herbarium Handbook. Royal Botanic Gardens, Kew.

Canhos DAL, Sousa-Baena MS, Souza S, Garcia LC, De Giovanni R, Maia LC, Bonacelli MBM (2013) Lacunas: a web interface to identify plant knowledge gaps to support informed decision-making. Biodiversity and Conservation 23: 109-131. doi: 10.1007/ s10531-013-0587-0

CGEN (2014) Conselho de Gestão do Patrimônio Genético - Ministério do Meio Ambiente. Published on the Internet. http://www.mma.gov.br/patrimonio-genetico/conselho-degestao-do-patrimonio-genetico [accessed 03.05.2014]

Chase MW, Hills HH (1991) Silica gel: an ideal material for field preservation of leaf samples for DNA studies. Taxon 40(2): 215-220. doi: 10.2307/1222975 
Christenhusz MJM, Reveal JL, Farjon A, Gardner MF, Mill RR, Chase MW (2011) A new classification and linear sequence of extant gymnosperms. Phytotaxa 19: 55-70.

Citadini-Zanette V (2013) Tributo ao Pe. Raulino Reitz e Roberto Miguel Klein. In: Sevegnani L, Schroeder E (Eds) Biodiversidade Catarinense: características, potencialidades, ameaças. Edifurb, Blumenau, 86-87.

Gasper AL de, Eisenlohr PV, Salino A (2013c) Climate-related variables and geographic distance affect fern species composition across a vegetation gradient in a shrinking hotspot. Plant Ecology \& Diversity. doi: 10.1080/17550874.2013.843604

Gasper AL de, Meyer L, Sevegnani L, Sobral M, Bonnet A (2012a) Flora vascular de Santa Catarina uma síntese do Inventário Florístico Florestal de Santa Catarina. In: Vibrans AC, Sevegani L, Gasper AL de, Lingner DV (Eds) Volume I - Inventário Florístico Florestal de Santa Catarina. Diversidade e Conservação dos Remanescentes Florestais. Edifurb, Blumenau, 110-125

Gasper AL de, Salino A, Vibrans AC, Sevegnani L, Verdi M, Korte K, Stival-Santos A, Dreveck S, Cadorin TJ, Schmitt JL, Caglioni E (2012b) Pteridófitas de Santa Catarina, um olhar sobre os dados do Inventário Florístico Florestal de Santa Catarina, Brasil. Acta Botanica Brasilica 26: 421-434.

Gasper AL de, Sevegnani L (2010) Lycophyta e samambaias do Parque Nacional da Serra do Itajaí, Vale do Itajaí, Santa Catarina, Brasil. Hoehnea 37(4): 755-767. doi: 10.1590/ S2236-89062010000400006

Gasper AL de, Sevegnani L, Vibrans AC, Sobral M, Uhlmann A, Lingner DV, Rigon-Júnior MJ, Verdi M, Stival-Santos A, Dreveck S, Korte A (2013a) Inventário florístico florestal de Santa Catarina: espécies da Floresta Ombrófila Mista. Rodriguésia 64: 201-210. doi: $10.1590 /$ S2175-78602013000200001

Gasper AL de, Uhlmann A, Sevegnani L, Lingner DV, Rigon-Júnior MJ, Verdi M, StivalSantos A, Dreveck S, Sobral M, Vibrans AC (2013b) Inventário Florístico Florestal de Santa Catarina: espécies da Floresta Estacional Decidual. Rodriguésia 64: 427-443. doi: $10.1590 /$ S2175-78602013000300001

Gaudeul M, Rouhan G (2013) A plea for modern botanical collections to include DNA-friendly material. Trends in Plant Science 18(4): 184-185. doi: 10.1016/j.tplants.2012.12.006

Hodkinson TR, Waldren S, Parnell JAN, Kelleher CT, Salamin K, Salamin N (2007) DNA banking for plant breeding, biotechnology and biodiversity evaluation. Journal of Plant Research 120(1): 17-29. doi: 10.1007/s10265-006-0059-7

Iganci JRV, Morim, MP (2012) Coleçóes botânicas para conservação: um estudo de caso em Abarema Pittier (Leguminosae, Mimosoideae). Revista Brasileira de Biociências 10(2): $164-170$.

IPNI (International Plant Names Index) (2012) Published on the Internet. http://www.ipni.org [accessed 02.05.2014]

Klein RM (1967) Aspectos do problema "Bromélia-Malária” no sul do Brasil. Sellowia 19: $125-135$.

Klein RM (1978) Mapa fitogeográfico do estado de Santa Catarina. In: Reitz R (Ed.) Flora Ilustrada Catarinense. Herbário Barbosa Rodrigues, Itajaí, 1-24.

Lingner DV, Schorn LA, Vibrans AC, Meyer L, Sevegnani L, Gasper AL de, Sobral M, Klemz G, Schmitt R, Anastacio-Jr C, Kruger A (2013a) Fitossociologia do componente arbóreo/ 
arbustivo da Floresta Ombrófila Densa no Estado de Santa Catarina. In: Vibrans AC, Sevegani L, Gasper AL de, Lingner DV (Eds) Volume IV - Inventário Florístico Florestal de Santa Catarina. Floresta Ombrófila Densa. Edifurb, Blumenau, 157-198.

Lingner DV, Sevegnani L, Gasper AL de, Uhlmann A, Vibrans AC (2013b) Grupos florísticos estruturais da Floresta Ombrófila Densa em Santa Catarina. In: Vibrans AC, Sevegani L, Gasper AL de, Lingner DV (Eds) Volume IV - Inventário Florístico Florestal de Santa Catarina. Floresta Ombrófila Densa. Edifurb, Blumenau, 141-155.

List of Species of Brazilian Flora (2014) Published on the Internet. http://floradobrasil.jbrj.gov. br/ [accessed 02.05.2014]

Meyer L, Gasper AL de, Sevegnani L, Lingner DV, Vibrans AC, Verdi M, Stival-Santos A, Dreveck S, Korte A (2012) Regeneração natural da Floresta Estacional Decidual em Santa Catarina. In: Vibrans AC, Sevegani L, Gasper AL de, Lingner DV (Eds) Volume II Inventário Florístico Florestal de Santa Catarina. Floresta Estacional Decidual. Edifurb, Blumenau, 163-183.

Meyer L, Gasper AL de, Sevegnani L, Schorn LA, Vibrans AC, Lingner DV, Verdi M, StivalSantos A, Dreveck S, Korte A (2013b) Regeneração natural da Floresta Ombrófila Densa no estado de Santa Catarina. In: Vibrans AC, Sevegani L, Gasper AL de, Lingner DV (Eds) Volume IV - Inventário Florístico Florestal de Santa Catarina. Floresta Ombrófila Densa. Edifurb, Blumenau, 201-245.

Meyer L, Gasper AL de, Sevegnani L, Schorn LA, Vibrans AC, Lingner DV, Verdi M, StivalSantos A, Dreveck S, Korte A (2013c) Regeneração natural da Floresta Ombrófila Mista no Estado de Santa Catarina. In: Vibrans AC, Sevegani L, Gasper AL de, Lingner DV (Eds) Volume III - Inventário Florístico Florestal de Santa Catarina. Floresta Ombrófila Mista. Edifurb, Blumenau, 191-222.

Meyer L, Sevegnani L, Gasper AL de, Schorn LA, Vibrans AC, Lingner DV, Sobral M, Klemz G, Schmitt R, Anastacio-Jr C, Brogni E (2013a) Fitossociologia do componente arbóreo/ arbustivo da Floresta Ombrófila Mista no Estado de Santa Catarina. In: Vibrans AC, Sevegani L, Gasper AL de, Lingner DV (Eds) Volume III - Inventário Florístico Florestal de Santa Catarina. Floresta Ombrófila Mista. Edifurb, Blumenau, 157-189.

Miszinski J, Souza JM de, Carrião SL, Antunes EN, Maraschin F, Pinto ESP, Orsi V (2012) Sistemas de Informaçóes Florístico-Florestais de Santa Catarina - SIFFSC. In: Vibrans AC, Sevegnani L, Gasper AL de, Lingner DV (Eds). Volume I - Inventário Florístico Florestal de Santa Catarina. Diversidade e Conservação dos Remanescentes Florestais. Edifurb, Blumenau, 263-277.

Oliveira-Filho AT, Budke JC, Jarenkow JA, Eisenlohr PV, Neves DRM (2013) Delving into the variations in tree species composition and richness across South American subtropical Atlantic and Pampean forests. Journal of Plant Ecology. doi: 10.1093/jpe/rtt058

Øllgaard B (2012) Nomenclatural changes in Brazilian Lycopodiaceae. Rodriguésia 63: 479-482. doi: 10.1590/S2175-78602012000200020

Peixoto AL, Barbosa MRV, Menezes M, Maia LC (2006) Diretrizes e estratégicas para a modernização das coleçôes botânicas brasileiras com base na formação de taxonomistas e na consolidação de sistemas integrados de informação sobre biodiversidade. In: Egler I, Santos MM, Canhos VP (Eds). Diretrizes e estratégicas para a modernização de coleçôes biológi- 
cas brasileiras e a consolidação de sistemas integrados de informação sobre biodiversidade. Ministério da Ciência e Tecnologia, Brasília, 145-182.

Pyke GH, Ehrlich PR (2010) Biological collections and ecological/environmental research: a review, some observations and a look to the future. Biological Reviews of the Cambridge Philosophical Society 85(2): 247-266. doi: 10.1111/j.1469-185X.2009.00098.x

Reitz R (1965) Plano de coleção. In: Reitz R (Ed) Flora Ilustrada Catarinense. Herbário Barbosa Rodrigues, Itajaí, 70p.

Reveal JL, Chase MW (2011) APG III: Bibliographical Information and Synonymy of Magnoliidae. Phytotaxa 19: 71-134.

Rothfels CJ, Sundue MA, Kuo LY, Larsson A, Kato M, Schuettpelz E, Pryer KM (2012) A revised family-level classification for eupolypod II ferns (Polypodiidae: Polypodiales). Taxon 61: 515-533.

Santos FR, Guimarães PEM, Redondo RAF (2002) Bancos de DNA: coleções estratégicas para estudos da biodiversidade. Lundiana 3(1): 93-98.

Schatz GE (2002) Taxonomy and Herbaria in Service of Plant Conservation: Lessons from Madagascar's Endemic Families. Annals of the Missouri Botanical Garden 89: 145-152. doi: $10.2307 / 3298559$

Schorn LA, Lingner DV, Vibrans AC, Gasper AL de, Sevegnani L, Sobral M, Meyer L, Klemz G, Schmitt R, Anastacio-Jr C, Kruger A (2012) Estrutura do componente arbóreo/arbustivo da Floresta Estacional Decidual em Santa Catarina. In: Vibrans AC, Sevegani L, Gasper AL de, Lingner DV (Eds) Volume II - Floresta Estacional Decidual. Edifurb, Blumenau, 139-159.

Sevegnani L, Gasper AL de, Bonnet A, Sobral M, Vibrans AC, Verdi M, Stival-Santos A, Dreveck S, Korte A, Schmitt JL, Cadorin TJ, Oliveira CPL, Caglioni E, Torres JF, Meyer L (2013a) Flora vascular da Floresta Ombrófila Densa em Santa Catarina. In: Vibrans AC, Sevegani L, Gasper AL de, Lingner DV (Eds) Volume IV - Inventário Florístico Florestal de Santa Catarina. Floresta Ombrófila Densa. Edifurb, Blumenau, 127-139.

Sevegnani L, Vibrans AC, Gasper AL de (2013b) Consideraçóes finais sobre a Floresta Ombrófila Densa e Restinga. In: Vibrans AC, Sevegani L, Gasper AL de, Lingner DV (Eds) Volume IV - Inventário Florístico Florestal de Santa Catarina. Floresta Ombrófila Densa. Edifurb, Blumenau, 325-327.

Sevegnani L, Vibrans AC, Gasper AL de (2013c) Considerações finais sobre a Floresta Ombrófila Mista em Santa Catarina. In: Vibrans AC, Sevegani L, Gasper AL de, Lingner DV (Eds) Volume III - Inventário Florístico Florestal de Santa Catarina. Floresta Ombrófila Mista. Edifurb, Blumenau, 275-278.

Smith AR, Pryer KM, Schuettpelz E, Korall P, Schneider H, Wolf PG (2006) A classification for extant ferns. Taxon 55: 705-731. doi: 10.2307/25065646

Smith GF, Figueiredo E (2009) E-taxonomy: an affordable tool to fill the biodiversity knowledge gap. Biodiversity and Conservation 19: 829-836. doi: 10.1007/s10531-009-9738-8

Smith GF, Roux JPK, Raven P, Figueiredo E (2011) African Herbaria Support Transformation on the Continent. Annals of the Missouri Botanical Garden 98: 272-276. doi: $10.3417 / 2010050$

Smith LB, Downs RJ (1964) Kleinodendron, novo gênero de Euforbiáceas. Sellowia 16: 175-178. 
Stehmann JR, Forzza RC, Salino A, Sobral M, Costa DP, Kamino LHY (2009) Plantas da Floresta Atlântica. Instituto de Pesquisas Jardim Botânico do Rio de Janeiro, Rio de Janeiro.

Uhlmann A, Gasper AL de, Sevegnani L, Vibrans AC, Meyer L, Lingner DV (2012) Fitogeografia de Santa Catarina. In: Vibrans AC, Sevegani L, Gasper AL de, Lingner DV (Eds) Volume I - Inventário Florístico Florestal de Santa Catarina. Diversidade e Conservação dos Remanescentes Florestais. Edifurb, Blumenau, 113-126.

Veloso HP, Klein RM (1957) As comunidades e Associaçóes vegetais da mata pluvial do sul do

Brasil - I. As comunidades do município de Brusque, Estado de Santa Catarina. Sellowia 8: 81-236.

Veloso HP, Klein RM (1959) As comunidades e associaçóes vegetais da Mata Pluvial do Sul do Brasil - II. Dinamismo e fidelidade das espécies em associaçóes do Município de Brusque, Estado de Santa Catarina. Sellowia 10: 9-124.

Veloso HP, Klein RM (1961) As comunidades e associaçóes vegetais da mata pluvial do sul do Brasil - III. As associaçóes das planícies costeiras do quaternário, situadas entre o Rio Itapocu (Estado de Santa Catarina) e a Baia de Paranaguá (Estado do Paraná). Sellowia 13: 205-261. Veloso HP, Klein RM (1963) As comunidades e associaçóes vegetais da mata pluvial do sul do Brasil - IV. As associaçóes situadas entre o rio Tubarão e a Lagoa dos Barros. Sellowia 15: 57-114.

Veloso HP, Klein RM (1968a) As comunidades e associaçóes vegetais da mata pluvial do Sul do Brasil - V. Agrupamento arbóreos dos contra-fortes da Serra Geral situados ao sul da costa Catarinense e ao norte da costa sul-riograndense. Sellowia 20: 127-180.

Veloso HP, Klein RM (1968b) As comunidades e associaçóes vegetais da mata pluvial do Sul do Brasil - V. Agrupamentos arbóreos da encosta catarinense, situados em sua parte Norte. Sellowia 20: 53-126.

Vibrans AC, Bonnet A, Caglioni E, Gasper AL de, Lingner DV (2013a) Volume V - Inventário Florístico Florestal de Santa Catarina. Epífitos Vasculares da Floresta Ombrófila Densa. Edifurb, Blumenau.

Vibrans AC, Sevegnani L, Gasper AL de (2012c) Consideraçóes finais sobre a Floresta Estacional Decidual em Santa Catarina. In: Vibrans AC, Sevegani L, Gasper AL de, Lingner DV (Eds) Volume II - Inventário Florístico Florestal de Santa Catarina. Floresta Estacional Decidual. Edifurb, Blumenau, 225-228

Vibrans AC, Sevegnani L, Gasper AL de, Lingner DV (2012a) Volume I - Inventário Florístico Florestal de Santa Catarina. Diversidade e Conservação dos Remanescentes Florestais. Edifurb, Blumenau.

Vibrans AC, Sevegnani L, Gasper AL de, Lingner DV (2012b) Volume II - Inventário Florístico Florestal de Santa Catarina. Floresta Estacional Decidual. Edifurb, Blumenau.

Vibrans AC, Sevegnani L, Gasper AL de, Lingner DV (2013b) Volume III - Inventário Florístico Florestal de Santa Catarina. Floresta Ombrófila Mista. Edifurb, Blumenau.

Vibrans AC, Sevegnani L, Gasper AL de, Lingner DV (2013c) Volume IV - Inventário Florístico Florestal de Santa Catarina. Floresta Ombrófila Densa. Edifurb, Blumenau.

Vibrans AC, Sevegnani L, Lingner DV, Gasper AL de, Sabbagh S (2010) Inventário florístico florestal de Santa Catarina (IFFSC): aspectos metodológicos e operacionais. Pesquisa Florestal Brasileira 30: 291-302. doi: 10.4336/2010.pfb.30.64.291 
Wu Q, Thiers BM, Pfister DH (2004) Preparation, Preservation, and Use of Fungal Specimens in Herbaria. In: Mueller GM, Bills GF, Foster MS (Eds) Biodiversity of fungi - inventory and monitoring methods. Academic Press, London: 23-36. doi: 10.1016/B978$012509551-8 / 50005-2$ 
